\title{
Probiotics and Postbiotics as Substitutes of Antibiotics in Farm Animals: A Review
}

\author{
Daria Zamojska $^{1,2, *(\mathbb{D})}$, Adriana Nowak ${ }^{2, *(\mathbb{D}}$, Ireneusz Nowak ${ }^{3}$ (D) and Ewa Macierzyńska-Piotrowska $^{1}(\mathbb{D}$ \\ 1 Polwet-Centrowet Sp. z o.o., M. Konopnickiej 21, 98-100 Lask, Poland; emacierzynska@gmail.com \\ 2 Department of Environmental Biotechnology, Lodz University of Technology, Wolczanska 171/173, \\ 90-530 Lodz, Poland \\ 3 Faculty of Law and Administration, University of Lodz, Kopcinskiego 8/12, 90-232 Lodz, Poland; \\ inowak@wpia.uni.lodz.pl \\ * Correspondence: daria.zielinska@dokt.p.lodz.pl (D.Z.); adriana.nowak@p.lodz.pl (A.N.)
}

Citation: Zamojska, D.; Nowak, A.; Nowak, I.; Macierzyńska-Piotrowska, E. Probiotics and Postbiotics as Substitutes of Antibiotics in Farm Animals: A Review. Animals 2021, 11, 3431. https://doi.org/10.3390/ ani11123431

Academic Editor: Valentina Virginia Ebani

Received: 20 October 2021

Accepted: 29 November 2021

Published: 1 December 2021

Publisher's Note: MDPI stays neutral with regard to jurisdictional claims in published maps and institutional affiliations.

Copyright: (c) 2021 by the authors. Licensee MDPI, Basel, Switzerland. This article is an open access article distributed under the terms and conditions of the Creative Commons Attribution (CC BY) license (https:// creativecommons.org/licenses/by/ $4.0 /)$.
Simple Summary: Breeders are searching for methods to protect farming animals against diseases caused by pathogenic bacteria. The easiest way to fight bacteria is to use antibiotics. Unfortunately, their abuse results in the presence of bacteria resistant to the most commonly used antibiotics in the environment. The restrictions on the use of antibiotics have forced the search for natural and safe ways to protect animals. It has been shown that the use of probiotics based on lactic acid bacteria may have a positive effect on the growth and use of feed by broilers, on the stabilization of the intestinal microbiota of chickens and pigs, and in the prevention of mastitis in dairy cows. The use of probiotics (live, nonpathogenic microorganisms) and postbiotics (inanimate bacteria, cell components or post-fermentation by-products) reduces the occurrence of pathogens in large-scale farms.

Abstract: Since 2006, the use of growth-promoting antibiotics has been banned throughout the European Union. To meet the expectations of livestock farmers, various studies have been carried out with the use of lactic acid bacteria. Scientists are trying to obtain the antimicrobial effect against the most common pathogens in large-scale farms. Supplementing the diet of broilers with probiotics (live, nonpathogenic microorganisms) stabilized the intestinal microbiota, which improved the results of body weight gain (BWG) and feed intake (FI). The positive effect of probiotics based on lactic acid bacteria has been shown to prevent the occurrence of diarrhea during piglet weaning. The antagonistic activity of postbiotics (inanimate bacteria, cell components, or post-fermentation by-products) from post-culture media after lactobacilli cultures has been proven on Staphylococcus aureus - the pathogen most often responsible for causing mastitis among dairy cows. The article aims to present the latest research examining the antagonistic effect of lactic acid bacteria on the most common pathogens in broilers, piglets, pigs, and cow farms.

Keywords: broiler; piglet; pig; bovine; lactic acid bacteria; probiotic; postbiotic; antibiotic; farm animal

\section{Introduction}

The invention of antibiotics is considered to be one of the greatest discoveries of the twentieth century and made it possible to control many diseases, but with their "overnormative" use, new threats appeared, including antibiotic resistanceto both human and veterinary medicinal products for animals [1]. It is obvious that the consumption of meat and meat products from animals fed with antibiotics (including their residues) is undoubtedly harmful to the health of the latter, and even more so to people, because even in a low concentration and regardless of the period time, it is not physiologically indifferent [2-5]. In other words, in animal husbandry, antibiotics should only be used for therapeutic purposes and not, inter alia, for reducing falls due to the crowding of animals in a small area, improving their condition, or stimulating growth and development. Thus, it is unacceptable to legally legalize the maximization of the fattening of farm animals through the use of 
antibiotics solely for strictly economic reasons [5]. The development of agriculture has led to the introduction of intensive livestock to satisfy parts of society around the world. Unfortunately, intensive industrial breeding increases density on farms and promotes the development of various diseases [6,7]. Crowded livestock production conditions facilitate the transmission of zoonotic pathogens, such as parasites, fungi, viruses, and bacteria among individuals $[8,9]$.

In 2019, the EU produced 43.5 million tons of meat, which was around $10 \%$ less than in 2018. From the number, approximately $52 \%$ came from pigs ( 22.8 million tons), 6.9 million tons were bovine meat, and 13.3 million tons were poultry. In the same year, the EU produced 158.2 million tons of raw milk. The European Union bred 143 million pigs, and 77 million cattle were also bred. The main producer of poultry meat in the EU was Poland (2.6 million tons) [10].

The sales of pharmaceutical forms of drugs in 31 countries accounted for $87.7 \%$ of the total sales of veterinary products: premixes accounted for $26.9 \%$, oral powder for $9 \%$, and solutions for $51.8 \%$. The sales of intramammary preparations amounted to $0.6 \%$. In the years 2011-2018, a decrease in sales by $34.6 \%$ was observed in 25 countries. Sales of tetracyclines (30.7\%), penicillins (28.8\%), and sulfonamides $(8.4 \%)$ in $\mathrm{mg} / \mathrm{PCU}$ accounted for $67.9 \%$ of total sales in 2018 [11]. One experiment showed an increased productivity of chickens after the administration of subtle doses of antibiotics, such as chlorotetracycline, virginiamycin, and amoxicillin. In animals fed with antibiotics, the feed conversion ratio (FCR) decreased, but in the feces samples, heterotrophic bacteria with antibiotic resistance were detected [12]. The overuse of antimicrobial agents in animal husbandry causes more and more frequent occurrences of pathogenic bacteria resistant to popular antibiotics [13].

In the review, the positive effect of the use of probiotics on achieving the balance of intestinal microorganisms and the antibiotic-like effect in inhibiting the growth of pathogenic microorganisms found in slaughter farms in chickens, pigs, piglets, and cattle is described. According to the definition used by The International Scientific Association for Probiotics and Prebiotics (ISAPP), a probiotic is a live, non-pathogenic microorganism with a positive effect on the host [14]. According to Williams (2010), microorganisms classified as probiotics are most often lactic acid bacteria (LAB), but also Bacillus cereus and Enterococcus faecalis [15]. Probiotic bacteria, in particular LAB, are used to obtain fermented dairy products, e.g., Greek yogurt (S. thermophilus ACA-DC 26), feta cheese (L. plantarum ACADC 2640) [16], kefir [17,18], and fermented vegetables, e.g., sauerkraut $[19,20]$. Consuming probiotics shows a health-promoting effect for humans [21,22]. Likewise, probiotics protect food against the development of pathogens and spoilage [22,23]. The review also describes the positive effects of postbiotics on the animals' gut microbiome.

The latest ISAPP definition says that postbiotics are inanimate microorganisms or bacterial cell components and that post-fermentation by-products such as lactic acid and short chain fatty acids (SCFA) positively affect the host [14]. According to Pandey et al. (2015), a synbiotic is a food component or dietary supplement consisting of an appropriate combination of a probiotic and a prebiotic [24]. The ISAPP gave a more precise definition of synbiotic. Synbiotic causes a positive effect on the health of the host, and it is a mixture of microorganisms and nutrients used by the host's microorganisms [25]. A prebiotic is a substance used by microorganisms that has a positive effect on its growth [14]. In the cited example, the prebiotic was the polysaccharide inulin [26] added to the probiotic mix of LAB bacteria [27] (Figure 1).

This article discusses the latest research on the effects and benefits of LAB and their metabolites on the intestinal microbiota of the most common farm animals: poultry, bovines, and pigs. The review covers the newest literature on the application of probiotics and postbiotics in nutrition and in improving the welfare of farm animals. In addition, the future legal regulations regarding antibiotics in the European Union are discussed. 


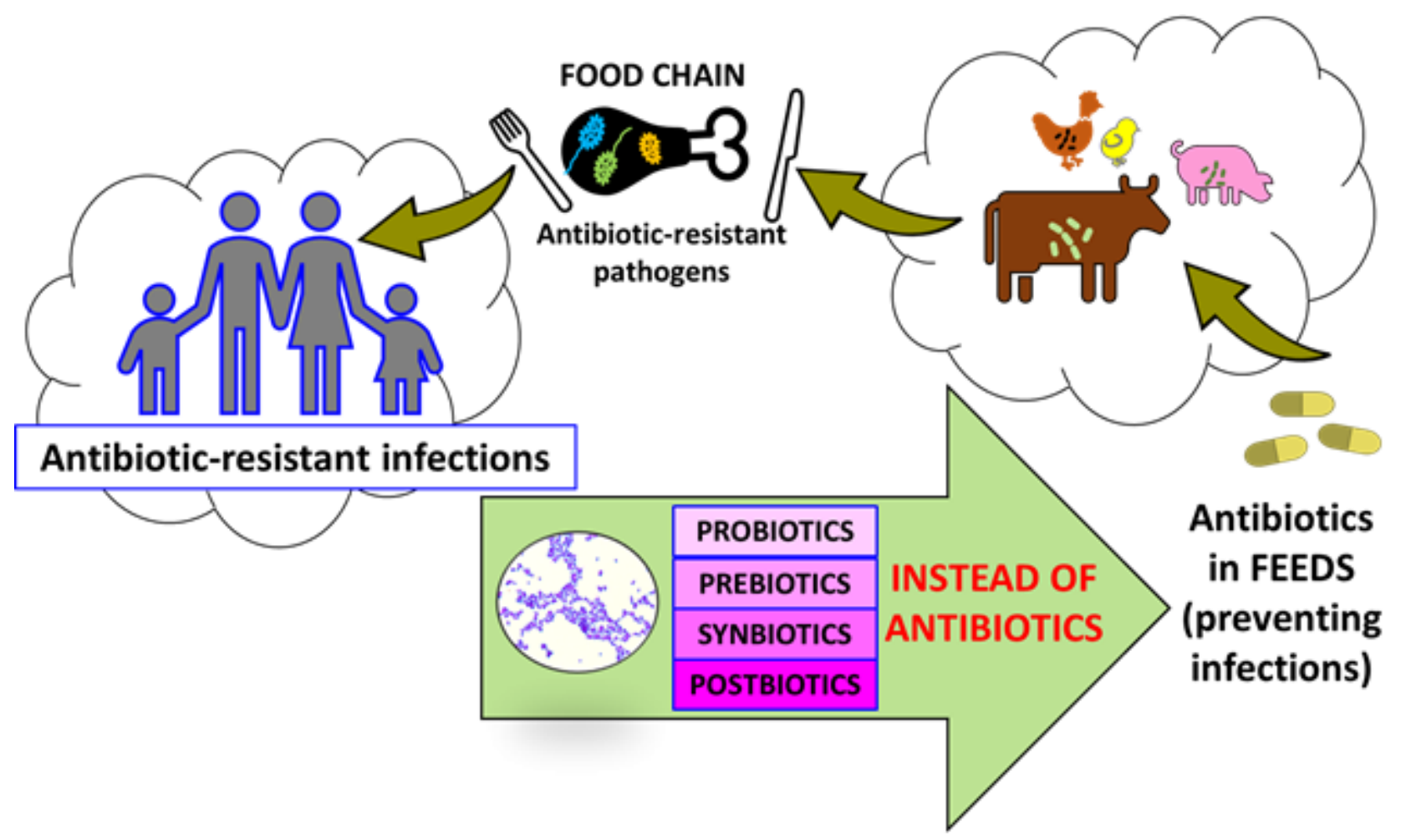

Figure 1. Effect of antibiotics application in animal husbandry.

\section{The Welfare Improving Poultry Farming}

The most common pathogen in the poultry gastrointestinal tract in broiler breeding is the Salmonella species. Due to the limitation of the use of antibiotics, research is conducted with the use LAB bacteria in order to limit the colonization of the intestines by Salmonella sp. Wang et al. vaccinated hatched chicks with a strain of Lactiplantibacillus plantarum LTC-113. Studies have shown protection against Salmonella Typhimurium by reducing gut colonization and stabilizing tight junction gene expression in intestinal epithelial cells among treated chickens. In the control group, a Salmonella infection disrupted the intestinal epithelial barrier [28].

In contrast, another study reported that orally administered Lactobacillus johnsonii reduced intestinal colonization by Salmonella and Clostridium perfringens [29]. In another variant, the probiotic was given combined with two strains: Ligilactobacillus salivarius and Enterococcus faecium. The probiotic reduced intestinal colonization by Salmonella Enteritidis and did not cause weight loss or damage to the gastrointestinal mucosa [30]. In another experiment, the use of the E. faecium probiotic in feed increased egg weight, serum FSH (follicle-stimulating hormone) levels, and decreased Bacteroidetes (phylum) in low reproductive individuals [31]. Salmonella enters the bloodstream and then goes to the liver and spleen through damage to the intestinal barrier, which has been confirmed in many studies [32-34].

The administration of LAB bacterial cell membrane extracts to chickens reduced the Salmonella Enteritidis infection. Considerable protection of the intestinal epithelium against the effects of infection was evident [32]. The next experiment was very similar, however, a commercial probiotic based on LAB with proven efficacy against $S$. Enteritidis was used for treatment. The study aimed to understand the effect of a probiotic on intestinal colonization and intestinal permeability in infected chickens. The results were very promising. After infection of the control group with Salmonella pathogens, heterophilia and lymphopenia were observed as well as an increase in basophils and eosinophils compared to the chickens treated with a probiotic based on LAB bacteria. In the control group, increased intestinal permeability was also found [33]. In another experiment, the probiotic Bacillus subtilis 
C-3102 was used to control S. enteric serovar enteritidis LM-7. The specific pathogen-free chicks became infected by administering an appropriate dose of Salmonella in the food. Supplementation with B. subtilis feed reduced Salmonella infections and may accelerate the clearance of pathogens in the liver, cecum, and spleen of chicken farms [34].

Han et al. (2017) orally administered Pediococcus acidilactici mutants to chickens, modulating the microbiota and reducing the number of Salmonella enterica serovar Gallinarum, which is often found in the poultry industry. The study proved the antimicrobial activity of $P$. acidilactici. After treatment of the cultures with proteinase, the antimicrobial activity decreased, which may suggest the production of proteinaceous substances such as bacteriocin by $P$. acidilactici [35].

Another common pathogen on farms is Campylobacter sp. The pathogen is rapidly transmitted on poultry farms via the fecal-oral route. The study of Ščerbová et al. (2016) assessed the inhibition spectrum of various enterocins against Campylobacter sp. Enterocins are protein substances with antibacterial activity metabolized mainly by enterococci. The isolated strains from poultry farming were divided into two groups, Campylobacter jejunum, and Campylobacter coli. Interestingly, the strains showing resistance to antibiotics displayed sensitivity to at least one of the nine eneterocins tested [36]. On the other hand, Razmyar et al. (2017) showed that C. perfringens secretes bacteriocins, which may be responsible for facilitating intestinal colonization and causing intestinal inflammation by this pathogen [37]. Supernatants from Lactobacillus acidophilus NCFM, Lactobacillus crispatus JCM 5810, Lactobacillus gallinarum ATCC 33199, and Lactobacillus helveticus CNRZ32 cultures inhibited the growth of $C$. jejuni in vitro. After the analyses, the substance responsible for limiting the growth of $C$. jejuni was partly lactic acid. Subsequently, in in vivo studies, LAB was administered to broilers on the day of hatching, on the fourth day after hatching, and 14 days after hatching, challenged with C. jejuni F38011. Each of the four strains limited the colonization of the pathogen. It was most effective in limiting the colonization of L. crispatus JCM 5810 [38].

Another pathogenic bacterium on chicken farms is avian E. coli (APEC). Birds infected with APEC show macroscopic changes in air sacs and lungs [39]. In the experiment of Li et al. (2021), Lactobacillus animalis (ATCC 35046), Lactobacillus reuteri (ATCC 2837), and Lactobacillus rhamnosus (ATCC 23272) strains were injected into the eggs to inhibit APEC infection. However, no differences were noted in APEC-like strains infection in the probiotic-administered group and control group [40]. This result was completely different from that obtained in the experiment in which the probiotic mix with B. subtilis, Clostridium butyricum, and L. plantarum was used. The applied probiotic lowered the E. coli index in infected chickens. The positive effect of the probiotic on the modulation of the intestinal microbiota of broilers has also been proven [41].

The protection of poultry farms against microbes is one of the most important factors in good breeding. However, it is also an important factor to improve European indicators for weight gain and feed consumption. The study of Kierończyk et al. (2017) aimed to test the effect of nisin on growth efficiency, morphological parameters, the activity of digestive enzymes, the digestibility of nutrients, and the effect on intestinal morphology in chickens. It was noticed that supplementing the diet of chickens with nisin, which is a bacteriocin used in the preservation of food products [42], improved the body weight gain (BWG), feed conversion ratio (FCR), and feed intake (FI) indexes [43]. According to Hsu et al. (2004), nisin is a cyclic polypeptide that contains 34 amino acids. The lactic acid bacteria of the genus Lactococcus lactis, carries out the fermentation process and, in addition to lactic acid, produces the bacteriocin nisin. Nisin is a natural antibiotic against Gram-positive bacteria $[44,45]$. Research has indicated that nisin can be used as a growth simulator without adversely affecting the bird's metabolism or immunity levels [28]. According to Kierończyk et al. (2020), nisin can be considered as a new and natural growth promoter. It improves digestibility and feeds conversion. By limiting the multiplication of pathogenic bacteria, nisin has a positive influence on the modulation of the intestinal microbiota. In terms 
of its antibacterial properties, it is similar to monensin, an antibiotic of the coccidiostatic type [46].

The intestinal microbiota was modulated not only with probiotics but also with plant feed additives. Wang et al. (2021) showed a positive effect of dietary purslane in the experiment. Purslane (Portulaca oleracea L.) is an edible wild vegetable with medicinal properties. The use of purslane in the feed increased the level of Lactobacillus and lowered Escherichia/Shigella in the digestive tract of broilers. The growth of beneficial bacteria in chicken intestines may promote high body weight gain [47]. Another study by Liang et al. (2021) applied traditional Chinese medicine based on medicinal plants combined with probiotics - a mix of B. subtilis and L. acidophilus. In the treatment of E. coli-infected chickens, the mix inhibited the survival level of $E$. coli, reduced the rates of diarrhea and mortality, improved body weight gain, and relieving pathological changes in the intestines and liver were observed [48].

In another study confirming the beneficial effect of LAB on the intestinal microbiota of fattening chickens conducted by Śliżewska et al. (2020), the effects of three variants of synbiotics were compared with two variants of a commercial probiotic on the chicken's performance. The synbiotics were three combinations containing the following strains: L. plantarum ŁOCK 0860, L. reuteri ŁOCK 1092, L. pentosus ŁOCK 1094, Saccharomyces cerevisiae ŁOCK 0119, L. rhamnosus ŁOCK 1087, L. paracasei ŁOCK 1091, and 2\% inulin (prebiotic). Commercial probiotics included BioPlus YC (Bacillus licheniformis DSM 5749, B. subtilis DSM 5750) and Cylactin (Enterococcus faecium NCIMB 10415). The positive effect of synbiotics on the performance of fattening chickens and the balance of the intestinal microbiota was demonstrated. The number of beneficial microorganisms such as Bifidobacterium sp. and Lactobacillus sp. increased in the intestines, and the number of pathogenic bacteria such as Clostridium sp. and E. coli in the intestines and animal excretions decreased. The change in the gut microbiome increased the levels of lactic acid and SCFA (short chain fatty acid). This is another study confirming the beneficial effect of LAB on the intestinal microbiota of fattening chickens [27].

The Gram-negative bacteria Gallibacterium anatis is responsible for the decrease in the number of eggs laid by causing infections of the genital tract of hens and contributes to increased mortality [49,50]. A study conducted by Zhang et al. (2021) showed the antagonistic activity of the supernatant after the culture of Leuconostoc mesenteroides QZ1178 (a species of lactic acid bacteria) was used against G. anatis strains in vitro. The antagonistic effect was decreased upon increasing the $\mathrm{pH}$. After analysis of the supernatant, L. mesenteroides QZ1178 mainly produced lactic acid $(29 \mathrm{mg} / \mathrm{mL})$ and acetic acid $(7 \mathrm{mg} / \mathrm{mL})$, which are probably responsible for its antibacterial properties [51]. The above information is summarized in Table 1.

Table 1. Overview of the application of beneficial bacteria in poultry farming in an in vivo study.

\begin{tabular}{|c|c|c|c|}
\hline Probiotic/Postbiotic/Synbiotic & Form/Way of Administration & Effect & References \\
\hline $\begin{array}{l}\text { Lactiplantibacillus plantarum } \\
\text { LTC-113 }\end{array}$ & vaccination & $\begin{array}{l}\text { Protection against Salmonella Typhimurium; } \\
\text { stabilizing intestinal epithelial barrier }\end{array}$ & [28] \\
\hline Lactobacillus johnsonii & per os in feed & $\begin{array}{c}\text { Reduction of Salmonella sofia and Clostridium } \\
\text { perfringens }\end{array}$ & [29] \\
\hline $\begin{array}{c}\text { Ligilactobacillus salivarius } 59 \text { and } \\
\text { Enterococcus faecium } \\
\text { PXN33/probiotic }\end{array}$ & per os in feed & $\begin{array}{l}\text { Decreased colonization by Salmonella Enteritidis } \\
\qquad 51400\end{array}$ & {$[30]$} \\
\hline E. faecium/probiotic & per os in feed & $\begin{array}{c}\text { Increased egg weight, serum FSH * levels, } \\
\text { decreased Bacteroidetes }\end{array}$ & [31] \\
\hline Bacillus subtilis C-3102/probiotic & per os in feed & $\begin{array}{l}\text { Reduction of Salmonella eteric serovar enteritidis } \\
\text { LM-7 }\end{array}$ & {$[34]$} \\
\hline Pediococcus acidilactici & per os in feed & $\begin{array}{c}\text { Reduction of Salmonella enterica serovar } \\
\text { Gallinarum }\end{array}$ & [35] \\
\hline
\end{tabular}


Table 1. Cont.

\begin{tabular}{|c|c|c|c|}
\hline Probiotic/Postbiotic/Synbiotic & Form/Way of Administration & Effect & References \\
\hline $\begin{array}{l}\text { Lactobacillus acidophilus NCFM, } \\
\text { Lactobacillus crispatus JCM 5810, } \\
\text { Lactobacillus gallinarum ATCC } \\
\text { 33199, and Lactobacillus helveticus } \\
\text { CNRZ32 }\end{array}$ & per os in feed & Inhibition of the growth of Campylobacter jejuni & [38] \\
\hline $\begin{array}{l}\text { B. subtilis MORI 91, Clostridium } \\
\text { butyricum M7 and L. plantarum } \\
\text { K34/commercial probiotic mix }\end{array}$ & per os in feed & $\begin{array}{l}\text { Lowered rate of E. coli; positive modulation of the } \\
\text { intestinal microbiota }\end{array}$ & [41] \\
\hline Nisin/postbiotic & per os in feed & $\begin{array}{l}\text { Natural growth promotor; positive influence on } \\
\text { the modulation of the intestinal microbiota; } \\
\text { limitation of pathogens in the gut }\end{array}$ & {$[42,46]$} \\
\hline $\begin{array}{l}\text { Chinese medicinal plants and } B . \\
\text { subtilis, L. acidophilus (probiotic) }\end{array}$ & per os in water & $\begin{array}{l}\text { Inhibition of E. coli; reduction of mortality; } \\
\text { improvement BWG* }\end{array}$ & [48] \\
\hline $\begin{array}{l}\text { L. plantarum ŁOCK 0860, L. reuteri } \\
\text { ŁOCK 1092, L. pentosus ŁOCK } \\
\text { 1094, Saccharomyces cerevisiae } \\
\text { ŁOCK 0119, L. rhamnosus ŁOCK } \\
\text { 1087, L. paracasei ŁOCK } 1091 \text { and } \\
\text { 2\% inulin (synbiotic) }\end{array}$ & per os in feed & $\begin{array}{l}\text { Increase of Bifidobacterium sp. and Lactobacillus sp.; } \\
\text { decrease in the level of Clostridium sp. and E. coli }\end{array}$ & [27] \\
\hline $\begin{array}{l}\text { L. plantarum CCTCC M2016259, } \\
\text { Paenibacillus polymyxa } \\
\text { CGMCC1.1711 }\end{array}$ & per os in feed & $\begin{array}{l}\text { The positive effect of intestinal health and } \\
\text { intestinal microbiota, improved body weight and } \\
\text { feed conversion in C. perfringens-infected; } \\
\text { increased intestinal SCFAs * levels }\end{array}$ & {$[52,53]$} \\
\hline L. acidophilus & per os in feed & $\begin{array}{l}\text { Increased body weight; reduced mortality; } \\
\text { improvement of the immune response in E. coli } \\
\text { O157-challenged chickens }\end{array}$ & [54] \\
\hline B. subtilis & per os in feed & $\begin{array}{l}\text { Increased FCR*, villus height to crypt depth ratio, } \\
\text { and number of Blautia, Faecalibacterium, } \\
\text { Flavonifractor, Hydrogenoanaerobacterium, and } \\
\text { Romboutsia; decreased Odoribacter; improvement } \\
\text { intestinal microbial composition }\end{array}$ & [55] \\
\hline B. subtilis PB6 & per os in feed & $\begin{array}{l}\text { Increased calcium and phosphorus in plasma; } \\
\text { increased bone mass and meat quality; } \\
\text { improvement production and welfare }\end{array}$ & [56] \\
\hline B. subtilis QST713 & per os in feed & $\begin{array}{l}\text { Increased level of Lactobacillus spp.; decreased } \\
\text { level of E. coli and Enterococcus spp.; elongated villi; } \\
\text { fewer deep crypts }\end{array}$ & [57] \\
\hline \multirow[b]{2}{*}{ B. subtilis DSM 29784} & \multirow[b]{2}{*}{ per os in feed } & $\begin{array}{l}\text { Increased } \mathrm{FCR}^{*} \text {, numbers of goblet cells, and } \\
\text { superoxide dismutase activities in the jejunal } \\
\text { mucosa; elongated villi }\end{array}$ & [58] \\
\hline & & $\begin{array}{l}\text { Improved health, weight, the tight junction } \\
\text { complex in necrotic enteritis-challenged broilers; } \\
\text { increased numbers of Butyricicoccus and } \\
\text { Faecalibacterium in the intestine; raised expression } \\
\text { of INF- } \gamma \text { and IL-12 }\end{array}$ & [59] \\
\hline E. faecium PNC01 & per os in feed & $\begin{array}{l}\text { Inhibition of the growth of Salmonella typhimurium; } \\
\text { elongated villi; reduced the length of jejunum and } \\
\text { ileum; increased number of Firmicutes and } \\
\text { Lactobacillus; reduced the number of Bacteroides }\end{array}$ & [60] \\
\hline
\end{tabular}

* FSH—follicle-stimulating hormone; BWG—body weight gain; SCFA—short-chain fatty acids; FCR—feed conversion ratio.

\section{Prevention of the Effects of Piglet Weaning Based on the Use of LAB}

The critical moment in breeding is weaning the piglets from sow on day 28. Pigs are very sensitive to changes in their living environment. This is a very stressful time for piglets, causing destabilization of the intestinal microbiota. During this time, digestive disorders, diarrhea, growth retardation, and increased mortality occur [61-64]. The most common pathogens affecting intestinal disorders and damage to intestinal villi are E. coli, C. perfringens, Salmonella Choleraesuis, and Salmonella Typhimurium. In the case of infection, 
the permeability of fluids to the intestinal lumen increases and diarrhea develops. There is also an increase in $\mathrm{pH}$, which prevents the multiplication of LAB [65].

Antibiotics are used to improve the intestinal microbiota and reduce the occurrence of diarrhea caused by weaning. The overuse of antibiotics has resulted in the emergence of pathogenic bacteria resistant to the basic antibiotics used in farming. Moreover, in the case of pig farms, research on the use of LAB to improve the intestinal microbiota was started [66].

Verso et al. (2018) isolated 595 pure cultures of bacteria from the small and large intestines from pre and post-weaned piglets. The selected bacteria were antagonistics to pathogens and were capable of producing antimicrobial compounds. First, the activity against pathogens E. coli MC4100, S. Choleraesuis ATCC 29628, and Listeria innocua HPB13 was tested using the Double-Agar-Layer Technique Method. At total of $51.1 \%$ of all strains showed antimicrobial activity and passed the next test to investigate the production of antimicrobial compounds. For this, the $\mathrm{pH}$ of the supernatant was neutralized with $1 \mathrm{M} \mathrm{NaOH}$. Activity against previous pathogens and Staphylococcus aureus ATCC 6538, Enterococcus faecalis ATCC 27275, Listeria monocytogenes LSD530, and S. Enterica ATCC 8387 was tested by the Agar-Well Diffusion Method. Loss of activity of some supernatants after protease treatment may indicate the presence of bacteriocin-like substances. These studies confirmed the ability of some LAB strains of the species L. salivarius and Lactobacillus delbrueckii subsp. lactis isolated from the digestive tract of pigs to inhibit the growth of potential pathogens by the production of organic acids in combination with bacteriocinlike proteins [67]. In another experiment, piglets were fed with an immunobiotic feed based on okara fermented soy milk with L. delbrueckii subsp. delbrueckii TUA4408L. The beneficial intestinal microbiota improved, the amount of Lactobacillus and Lactococcus increased, and the immunity also increased. The piglets showed better meat quality and growth performance [68]. In addition, the use of L. delebureckii CCTCC M 207,040 as a diet supplement by Chen et al. (2021) improved the gut structure resulting in increased gut integrity in lipolisaccharides (LPS)-challenged piglets. LPS stress induced an increase in the depth of the crypts in the jejunum and ileum. However, the use of L. delebureckii dietary supplementation reduced crypt depth compared to the non-challenged controls and LPS-challenged. Moreover, the TLRs-Btk-Nrf2 signaling pathway, which mediates oxidative stress, was mitigated [69]. Similar results were obtained in weaned piglets with C. butyricum ZJU-F1 and B. licheniformis. The intestinal permeability was reduced, and the digestibility of nutrients and the expression of antimicrobial peptides in the ileum improved [70]. In another experiment, Sobrino et al. (2021) isolated L. salivarius MP100 from sow's milk and gave inoculated feed to pregnant sows and piglets. MP100 showed antagonistic activity against the indicator bacteria: C. perfringens MP34, E. faecalis MP42, S. aureus MP83, Streptococcus suis MP205, Trueperella pyogenes MP214, E. coli MP73 (F4) and MP77 (F18), S. Typhimurium MP55, and Klebsiella pneumoniae MP87. The use of a potential probiotic resulted in a microbiological and biochemical improvement in the gut environment [71].

The Lactobacillus gasseri LA39 and Limosilactobacillus frumenti strains produce the substance gassericin A, which is a bacteriocin. A characteristic feature of this protein is that it binds to the intestinal epithelium of the host and makes it resistant to diarrhea in weaned piglets. Gassericin A bound to Keratin 19 in the plasma membrane of the intestinal epithelium increased the absorption of fluid from the intestine and reduced its secretion. The early weaning of piglets aims to shorten the slaughter cycle and improve the reproduction of the sows. In the experiment, fecal microbiota were taken from healthy Congjiang miniature pigs (a Chinese native pig breed) and administered orally to a commercial Landrace $\times$ Yorkshire (LY) pig, which shows frequent diarrhea after weaning. This treatment made the LY immune to stress-related diarrhea at weaning. The L. gasseri LA39 and L. frumenti strains can be an alternative to antibiotics in the prevention of diarrhea during increased stress in piglets [72]. In one study, the administration of L. salivarius (strains 144 and 160) to suckling piglets early in life resulted in an increase of the amount of Lactobacillus 
in the gastrointestinal tract and a reduction in the number of Bacteroides and Fibrobacter. The incidence of diarrhea during the most stressful time of weaning also decreased. The conclusions from the conducted research indicated the use of supplementation with L. salivarius 144 isolated from healthy pigs with a high BMI (body mass index), as it had a beneficial effect on increasing the height of intestinal villi, which influenced the pigs' growth efficiency. The same strain showed a reduction in the amount of Clostridium sp. in the feces [73].

Another way of administering LAB strains to pigs was to use of microcapsulation, i.e., administering LAB strains in sealed gelatin-alginate capsules. This method protects microorganisms against unfavorable conditions in the digestive tract. In the study of Le et al. (2019), the strains were isolated from traditional Vietnamese fermented yogurt. After the bacteria had multiplied, they were centrifuged, the supernatant was removed, and the remaining biomass was encapsulated. The L. plantarum SC01 strain showed antagonistic activity against E. coli, S. aureus, B. subtilis, Salmonella sp., and L. monocytogenes. It has been shown that the concentration of $2.5 \%(w / v)$ of alginate and $6 \%(w / v)$ of gelatin increases the production of a highly active compound that inhibits pathogens by LAB [74]. On the other hand, Pupa et al. (2021) used spray drying microencapsulation of L. plantarum 22F. The application of this method as well as alginate and chitosan usage for the production of capsules extended the viability of probiotic bacteria. The increased performance of pigs after microencapsulated probiotic supplementation was comparable to the use of live bacterial cultures. The alive bacteria: L. plantarum (strains $22 \mathrm{~F}$ and $25 \mathrm{~F}$ ) and P. acidilactici (strain $72 \mathrm{~N}$ ) were administered as potential probiotic supplements. The best effect in reducing pathogenic intestinal strains (Enterobacteriaceae) and modulating lactobacilli in the intestinal tract was obtained with the use of $P$. acidilactici $72 \mathrm{~N}$. The administration of the probiotics to young animals resulted in the improvement of intestinal integrity, elongation of intestinal villi in the jejunum, the appearance of microorganisms positively influencing the intestinal microbiome, and improved growth of individuals in the rearing cycle [75].

The weakening of the animals also occurs during pregnancy and the lactation of sows. Wang et al. (2014) isolated L. johnsonii XS4 from the gastrointestinal mucosa of healthy laboratory pigs. In previous studies, they demonstrated a high resistance of L. johnsonii XS4 to hydrochloric acid and bile salts and an antagonistic effect against the most common pathogens in culture (S. aureus, E. coli, S. Enterica). The sows were supplemented with freeze-dried L. johnsonii XS4 from day 90 of gestation to day 25 of lactation. It was noted that the supplementation resulted in an increase in the number of piglets weaned from the sow and an increase in litter weight by $14.45 \%$ compared to the control. In the supplemented group, there was a lower loss of backfat during lactation than in the control group, but it was not statistically significant. The obtained results indicate a positive effect on the production efficiency of the sows and the obtained litter. L. johnsonii XS4 has been presented as a promising alternative to the use of antibiotics in feed [76]. In another study, 295 LAB strains were tested, and three strains (Limosilactobacillus reuteri P7, Lactobacillus amylovorus $\mathrm{P} 8$, and L. johnsonii P15) with high growth-inhibitory activity for enterotoxigenic $E$. coli K88 were selected. The strains had a positive effect on the reproductive performance of sows and the growth of weaned piglets and reduced the occurrence of diarrhea [77].

In contrast, supplementation with E. faecium DSM 7134 increased food digestibility, gross weight, and gross energy. Moreover, in this case, the supplementation affected the sow's litter. The mortality of weaned pigs decreased, and weight gain of the piglets was noticeable. In this experiment, a reduced number of $E$. coli in feces was demonstrated after the piglets were weaned [78].

The administration of probiotic mixes to the sow, in this case, composed of L. delbrueckii subsp. bulgaricus, L. rhamnosus, L. acidophilus, L. plantarum, Streptococcus salivarius subsp. thermophilus, Bifidobacterium bifidum, E. faecium, Candida pintolopesii, and Aspergillus oryzae also gave satisfactory results. In this study, no diarrhea occurred in either the sows or the piglets. An increased concentration of acetic, propionic, and butyric acids in the 
feces was shown in piglets supplemented with the mix. However, in this case, the supplementation of the sows did not affect the litter weight, but there was a visible change in the gut environment of the piglets [79]. In the case of using only the dietary supplementation L. plantarum CAM6 in sows, it had a positive effect on body weight and reduced the occurrence of diarrhea in the offspring. The nutritional value of milk in sows improved [80]. The application of a diet with L. plantarum JL01 for weaned piglets resulted in better digestion and absorption of fats in the cecum and mediated the metabolism of tryptophan [81,82].

The interest of scientists was also aroused by the influence of a probiotic diet on bacteria present in the air. The effect of administering feed supplemented with E. faecalis CICC 23,215 in a piglet house over 60 days of airborne bacterial communities in the house was investigated. Air and feces samples were tested. The enrichment of air and feces with Lactobacillus species was shown. E. faecalis reduced the abundance of Proteobacteria, Acinetobacter sp., Escherichia sp., and Shigella sp. [83].

In another study by Wang et al. (2021), the effect of feeding with feed co-fermented by B. subtilis CW4 and E. faecium CWEF on lactating sows and newborn piglets was investigated. It was shown that the quality of the sows' milk was improved, which resulted in an increased weight gain in the piglets. There was a reduction in the incidence of constipation in sows and diarrhea in piglets, which was related to the modulation of the intestinal microflora. The sows showed better immunity and performance compared to the control [84]. Another experiment used the positive effects of Bacillus coagulans, oregano oil, and benzoic acid on the health, physiological, and physical condition of the piglets. An increased weight gain with a reduced feed ration was obtained in the diet supplemented with benzoic acid and B. coagulans. The addition of a third component to the diet-oregano oil-resulted in an increased number of bifidobacteria in the caecum and a decreased E. coli population in the cecum. Both the supplementation of the two-component and three-component diets positively influenced intestinal integrity, immunity, and physical condition of piglets in non-antibiotic breeding [85]. Similarly, in the study by Fu (2021), the use of $B$. coagulans and yeast hydrolysate in weaned piglets improved the intestinal barrier function, which resulted in better weight gain of the piglets. These two options can be used as alternatives to antibiotic growth promoters [86].

Not only LABs can be used as potential probiotics to prevent diarrhea. Swine commensal $E$. coli strains are bactericidal and compete in the environment with pathogenic porcine strains of E. coli. A reduced susceptibility of commensal E. coli to the 34 bacteriocin monoproducers was demonstrated compared to pathogenic E. coli. Finally, in vitro and in vivo, three potential probiotic E. coli were selected that could be candidates for the prophylaxis of post-weaning diarrhea [87]. The above information is briefly summarized in Table 2.

Table 2. Overview of the application of beneficial bacteria in pig and piglet farming in an in vivo study.

\begin{tabular}{|c|c|c|c|}
\hline Strains & Form/Way of Administration & Effect & References \\
\hline $\begin{array}{l}\text { Okara fermented soy milk with } \\
\text { L. delbrueckii subsp. delbrueckii } \\
\text { TUA4408L/probiotic }\end{array}$ & per os ${ }^{1}$ & $\begin{array}{l}\text { Better meat quality and growth } \\
\text { performance; increased level of lactobacilli } \\
\text { and Lactococcus }\end{array}$ & [68] \\
\hline L. delebureckii CCTCC M 207040/probiotic & \multirow[b]{2}{*}{ per os in feed ${ }^{1}$} & \multirow{2}{*}{$\begin{array}{l}\text { Reduced crypt depth in the jejunum and } \\
\text { ileum; increased gut integrity }\end{array}$} & [69] \\
\hline $\begin{array}{l}\text { C. butyricum ZJU-F1 and B. } \\
\text { licheniformis/probiotic }\end{array}$ & & & {$[70]$} \\
\hline L. salivarius MP100/probiotic & per os ${ }^{1,3}$ & $\begin{array}{c}\text { Antagonistic activity against C. perfringens } \\
\text { MP34, E. faecalis MP42, S. aureus MP83, } \\
\text { Streptococcus suis MP205, Trueperella } \\
\text { pyogenes MP214, E. coli MP73 (F4) and } \\
\text { MP77 (F18), S. Typhimurium MP55, and } \\
\text { Klebsiella pneumoniae MP87 }\end{array}$ & {$[71]$} \\
\hline $\begin{array}{l}\text { Lactobacillus gasseri LA39 and } \\
\text { Limosilactobacillus frumenti/probiotic }\end{array}$ & feces and saline solutions/per os ${ }^{2}$ & Prevent diarrhea after weaning & {$[72]$} \\
\hline L. salivarius 144 and $160 /$ probiotic & per os ${ }^{1}$ & $\begin{array}{c}\text { Increased level of lactobacilli and } \\
\text { reduction level of Bacteroides and } \\
\text { Fibrobacter in the gastrointestinal tract; } \\
\text { reduced diarrhea }\end{array}$ & {$[73]$} \\
\hline
\end{tabular}


Table 2. Cont.

\begin{tabular}{|c|c|c|c|}
\hline Strains & Form/Way of Administration & Effect & References \\
\hline L. plantarum SC01/probiotic & Microcapsulation/per os ${ }^{2}$ & $\begin{array}{c}\text { Antagonistic activity against E. coli, } \\
\text { S. aureus, B. subtilis, Salmonella sp., and } \\
\text { L. monocytogenes }\end{array}$ & {$[74]$} \\
\hline $\begin{array}{l}\text { L. plantarum } 22 \mathrm{~F} \text { and } 25 \mathrm{~F} \text {, and P. acidilactici } \\
72 \mathrm{~N} / \text { probiotic }\end{array}$ & $\begin{array}{c}\text { Spray drying } \\
\text { microencapsulation/per os }{ }^{2}\end{array}$ & $\begin{array}{l}\text { Improvement of intestinal integrity, } \\
\text { elongation of intestinal villi in the jejunum, } \\
\text { the appearance of microorganisms } \\
\text { positively influencing the intestinal } \\
\text { microbiome, and improved growth of } \\
\text { individuals in the rearing cycle }\end{array}$ & {$[75]$} \\
\hline L. johnsonii XS4/probiotic & Freeze-dried/per os ${ }^{3}$ & $\begin{array}{l}\text { Increased number of weaned piglets } \\
\text { increased litter weight }\end{array}$ & [76] \\
\hline $\begin{array}{c}\text { Limosilactobacillus reuteri P7, Lactobacillus } \\
\text { amylovorus } \mathrm{P} 8 \text {, and L. johnsonii } \\
\text { P15/probiotic }\end{array}$ & per os ${ }^{3}$ & $\begin{array}{l}\text { Positive effect on the reproductive } \\
\text { performance of sows and the growth of } \\
\text { weaned piglets and reduced the } \\
\text { occurrence of diarrhea }\end{array}$ & {$[77]$} \\
\hline E. faecium DSM 7134 & per os ${ }^{3}$ & $\begin{array}{l}\text { Reduced level of } E \text {. coli in feces after } \\
\text { weaning the piglets }\end{array}$ & {$[78]$} \\
\hline $\begin{array}{l}\text { L. delbrueckii subsp. bulgaricus, } \\
\text { L. rhamnosus, L. acidophilus, L. plantarum, } \\
\text { Streptococcus salivarius subsp. thermophilus, } \\
\text { Bifidobacterium bifidum, E. faecium, Candida } \\
\text { pintolopesii, and Aspergillus } \\
\text { oryzae/probiotic }\end{array}$ & per os ${ }^{1,3}$ & $\begin{array}{l}\text { Increased concentration of acetic, } \\
\text { propionic, and butyric acids in the feces }\end{array}$ & {$[79]$} \\
\hline L. plantarum CAM6/probiotic & per os $^{3}$ & Improved nutritional value of milk & {$[80]$} \\
\hline $\begin{array}{l}\text { B. subtilis CW4 and E. faecium } \\
\text { CWEF/probiotic }\end{array}$ & per os 1,3 & $\begin{array}{l}\text { Improvement in the quality of sows' milk; } \\
\text { better immunity at sows }\end{array}$ & [84] \\
\hline L. reuteri $1 /$ probiotic & freeze-dried/per os ${ }^{2}$ & $\begin{array}{l}\text { Increased carcass yield; improved meat } \\
\text { quality and flavor }\end{array}$ & {$[88]$} \\
\hline B. subtilis WB800 & per os $^{1}$ & Enhanced respiratory immunity & [89] \\
\hline
\end{tabular}

The experiment was carried out on 1-piglets, 2-pigs, 3-sows.

\section{Prevention of Udder Infections in Cattle with Particular Emphasis on Bacterioci Like-Substance}

Inflammation of a cow's udder, another name mastitis, is caused by physical trauma, chemical irritation, or bacterial infection. Mastitis can be identified in two types: clinical and subclinical. Clinical mastitis manifests itself with local and systemic symptoms. Redness, swelling, pain in the udder area, decreased appetite, increased temperature, reduced milk production, and a change in milk compounds are visible [90]. Subclinical mastitis does not alter the udder. Abnormal changes in milk are visible, such as an increased population of bacteria, a change in quality and compounds, reduced milk production, and an increased number of somatic cells [91]. Inflammation of the udder tissue has a negative impact on economical milk production and the animal's welfare due to pathologies causing edema, swelling, pain, inflammation, or udder fibrosis [92] and to a reduced reproductive efficiency [93]. Disease control is hindered by the causes of multifactorial occurrence and involving a large number of pathogens [94]. The main pathogens inducing mastitis are S. aureus, Streptococcus uberis, and Streptococcus dysgalactiae [95-97] and more often isolated strains of E. coli [98]. The treatment consists of identifying the pathogen and then administering an appropriate intramammary antibiotic [99]. Due to the excessive use of antibiotics, bacterial resistance increases and treatment efficacy decreases, so there is a growing interest in replacement therapies without antibiotics [100].

One experiment reviewed a large bank of engineered nisin modifications and discovered three new variants of nisin A M17Q, nisin A HTK, and nisin A T2L. These variants showed antibacterial activity against $S$. aureus strains associated with bovine mastitis. It has been shown to reduce the growth inhibition of commensal bacteria naturally occurring in milk, such as lactobacilli and lactococci. This is the next step in the development of substitutes for antibiotic therapies on farms [101]. 
Godoy-Santos et al. (2019) isolated the bovicin HC5 bacteriocin from the rumen bacteria Streptococcus equinus HC5. Bovicin HC5 is a lantibiotic with the ability to bind to lipid II in the cytoplasm such as nisin [102]. Other studies showed a bovicin HC5 bactericidal effect against L. monocytogenes, Salmonella Typhimurium, and some species of Clostridium and Bacillus [103,104]. The antibacterial effect of bovicin HC5 was tested in isolated strains from animals with mastitis. There were: S. aureus (99 strains), coagulated negative Staphylococcus sp. (CNS) (44 strains), Streptococcus agalactiae (71 strains), Streptococcus bovis (22 strains), S. uberis (20 strains), and E. coli (20 strains). Bovicin HC5 has inhibited the growth of most Streptococcus and Staphylococcus species. A total of 276 pathogenic isolates were tested. Some $18 \%$ of the isolates were not susceptible to the bacteriocin. None of the E. coli strains showed sensitivity to bovicin HC5. In the case of $S$. aureus, the pathogen most often responsible for the occurrence of mastitis in cows, as many as $95 \%$ of isolates showed the highest sensitivity to bovicin HC5 [102].

Due to the high costs of producing pure bacteriocins, other scientists decided to test the effect of a preparation containing live Lactococcus lactis DPC3147 cultures [105]. The effectiveness of the product was compared with the commercial antibiotic, Terrexine TM, which is used to treat cows with clinical and subclinical signs of mastitis. In cows with clinical symptoms, inflammation and/or malaise, clots, pathogens in milk, and poor milk production occurred. Cows infected with $S$. aureus and treated with biopreparation showed a cure rate of $45 \%$, and cows treated with a commercial antibiotic showed a cure rate of $50 \%$. The above data show that the biopreparation containing the bacteriocin lacticin 3147 produced by L. lactis DPC3147 shows comparable efficacy to the commercial antibiotic. Cows treated with the biopreparation showed an increased response of the immune system and a decrease in the number of somatic cells in milk. Five days after the injection into the replacement biopreparation, no DPC3147 cells were detected, which indicates that the animals quickly excrete the "live biopreparation". The above experience allows us to limit the administration of antibiotics in the treatment of mastitis in the future and shorten the withdrawal time of treated animals [105].

On the other hand, one of the in vitro studies demonstrated the bactericidal effect of the supernatant after the L. lactis ssp. lactis bacterial culture was used against the most common occurring mastitis pathogen. There were obtained uncleaned bacteriocins from supernatant after bacterial culture and used on pathogens. In this experiment, Malvisi et al. (2016) confirmed the presence of the class I bacteriocin, nisin A, in the supernatant by liquid chromatography. The highest antagonistic activity had L. lactis LL11 and SL153 supernatants after bacterial culture. Malvisi et al. (2016) applied the supernatant containing nisin A to the bovine mammary epithelial cell line BME-UV1. The stimulation of the secretion of NAGase and the LZ antibacterial enzymes by the cells was visible without causing damage or adverse inflammatory reactions, and there was no damage to cell integrity [106].

One study investigated the antimicrobial activity of 13 specific bacteria isolated in vitro from a honey bee cultivation against mastitis pathogens. Nine types of Firmicutes were isolated: Apilactobacillus kunkeei Fhon2, Apilactobacillus apinorum Fhon13, Bombilactobacillus mellis Hon2, Bombilactobacillus mellifer Bin4, Lactobacillus kullabergensis Biut2, Lactobacillus kimbladii Hma2, Lactobacillus helsingborgensis Bma5, Lactobacillus melliventris Hma8, and Lactobacillus apis Hma11 and 4 types of Actinobacteria: Bifidobacterium coryneforme Bma6, Bifidobacterium asteroides Bin2, Bifidobacterium sp. Bin7, and Bifidobacterium sp. Hma3. Three of the tested oxalicin-resistant $S$. uberis were inhibited by the use of a combination of a honey-based medium and 13 specific bacteria. The same was observed in ampicillin and trimethoprim-sulfamethoxazole-resistant E. coli isolates. The study demonstrated that 13 specific bacterial symbionts in combination with the heather honey matrix showed an inhibitory effect on the growth of mastitis pathogens [107].

In one of the experiments carried out by Seon-Gyu Kim et al. (2019), synergistic inhibition of the growth of $S$. aureus KCTC 3881 by bacteriocin and bacteriophage was used. The bacteriocin was isolated from L. lactis CJNU 3001. For comparison, bacteriocin and 
bacteriophage activity were also tested separately. Pure bacteriocins showed antagonistic activity against $S$. aureus depending on the dose. Visible effects were obtained at concentrations of 50 and $100 \mathrm{AU} / \mathrm{mL}$. The treatment of $S$. aureus with a dose of $1 \mathrm{MOI}$ (multiplicity of infection) of the SAP84 bacteriophage showed a viable cell count of $5.7 \mathrm{Log}$ CFU $/ \mathrm{mL}$. The combined action of phage $(0.1 \mathrm{MOI})$ and bacteriocin $(100 \mathrm{AU} / \mathrm{mL})$ showed a reduction in the number of viable S. aureus cells to $3.3 \mathrm{Log} \mathrm{CFU} / \mathrm{mL}$. The combination of bacteriocin and bacteriophages may be a promising strategy to combat pathogens not only associated with mastitis in cattle [108].

One of the metabolites produced by LAB is lactic acid [38,109]. Chotigarpa et al. (2018, 2019) performed the time-killing analysis of rice gel with $5 \%(v / v)$ lactic acid on E. coli ATCC 25,922 and E. coli field strains (teat skin samples from healthy dairy cows after washing udder) in the time interval of 0 to $60 \mathrm{~min}$. The study showed an inhibitory effect on the growth of E. coli, which means that created gel can reduce the number of pathogenic bacteria on the cows' teats. The gel can be an alternative to the antibiotics used and in the prevention of mastitis. Additionally, the minimum inhibitory concentration (MIC) and minimum bactericidal concentration (MBC) of pure lactic acid were checked for E. coli strains. The MIC and MBC were $0.5 \%$ lactic acid [110,111].

The analysis of feces in four dairy cows showed the presence of the following Lactobacillus strains: Lactobacillus gasseri, Limosilactobacillus reuteri, and Ligilactobacillus salivarius. In vitro, the supernatants of these strain cultures showed bactericidal activity against Escherichia coli O157:H7, Mycobacterium avium ssp. paratuberculosis, and the Salmonella species (Salmonella enteritidis, Salmonella typhimurium, and Salmonella Dublin). They also showed a low risk of lateral transfer of antibiotic-resistant genes despite showing resistance to streptomycin (L. gasseri) and kanamycin (L. salivarius). In an ex vivo study, they showed adherence to bovine intestinal epithelium cells. The use of such fecal isolates may be a species-specific probiotic for cattle [112]. The above information is briefly summarized in Table 3.

Table 3. Overview of the application of potential probiotic bacteria in bovine farming in an in vitro study.

\begin{tabular}{|c|c|c|c|}
\hline Probiotic/Postbiotic & Form/Way of Administration & Effect & References \\
\hline Nisin derivatives/postbiotic & Solution & Antibacterial activity against $S$. aureus & [101] \\
\hline Bovicin $\mathrm{HC} 5$ /postbiotic & Solution & $\begin{array}{l}\text { Bactericidal effect against L. monocytogenes, } \\
\text { Salmonella Typhimurium, and some } \\
\text { species of Clostridium and Bacillus }\end{array}$ & {$[103,104]$} \\
\hline L. lactis LL11 and SL153/postbiotic & Supernatant & $\begin{array}{l}\text { Bactericidal effect against the most } \\
\text { common occurring mastitis pathogen }\end{array}$ & [106] \\
\hline $\begin{array}{c}\text { Bacteriocin from L. lactis CJNU } \\
\text { 3001/postbiotic }\end{array}$ & Bacteriophage & $\begin{array}{l}\text { Inhibition of the growth of S. aureus } \\
\text { KCTC } 3881\end{array}$ & [108] \\
\hline $\begin{array}{l}\text { Lactobacillus gasseri, Limosilactobacillus } \\
\text { reuteri, and Ligilactobacillus } \\
\text { salivarius/postbiotic }\end{array}$ & Supernatant & $\begin{array}{l}\text { Bactericidal activity against Escherichia coli } \\
\text { O157:H7, Mycobacterium avium ssp. } \\
\text { paratuberculosis, and Salmonella species }\end{array}$ & [112] \\
\hline L. gasseri LA806 & Live and heat-inactived & $\begin{array}{l}\text { Inhibition of the growth of S. aureus; } \\
\text { barrier and immunomodulatory }\end{array}$ & [113] \\
\hline
\end{tabular}

\section{Antibiotics-Future Legal Regulations}

In order to counteract the phenomenon of antibiotic resistance and protect broadly understood public health, comprehensive actions, including legal ones, are necessary. In reference to the data provided by OECD (Organisation for Economic Cooperation and Development), it is estimated that about 700,000 deaths may be caused globally each year by AMR (antimicrobial resistance). Compared to a world with no AMR, the economic impact associated with current rates of AMR may reach about $0.03 \%$ of GDP in 2020 in OECD countries, $0.07 \%$ in 2030 , and $0.16 \%$ in 2050 . This would result in a cumulative loss of about USD 2.9 trillion (NB: in the quoted report, the amount 'trillion' means 1012-'Council conclusions on the next steps under a One Health approach to combat 
antimicrobial resistance' (2016/C 269/05), Official Journal of the European Union 23.7.2016) by 2050 [114]. Moreover, as shown by data published by the European Medicines Agency, the use of antibiotics in Europe is more than twice as high in the treatment of animals as in humans. From 2011 to 2014, the use of antibiotics in agriculture increased by $23 \%$ [115]. The basic legal act in the European Union in the field of the use of antibiotics, which will come into force on 28 January 2022, is Regulation (EU) 2019/6 of The European Parliament and of the Council on 11 December 2018 on veterinary medicinal products, and repealing Directive 2001/82/EC [116]. The above normative act will be directly applicable in all Member States, without the obligation to implement it into the national legal order.

According to the above-mentioned legal act, in Article 4 point 12 of the Regulation (EU), 'antibiotic' means any substance with a direct action on bacteria that is used for treatment or prevention of infections or infectious diseases. The antibiotic also fits into the broader definition adopted by the EU legislator, the so-called 'antimicrobial', which means any substance with a direct action on micro-organisms used for the treatment or prevention of infections or infectious diseases, including antibiotics, antivirals, antifungals and antiprotozoals) [116]. It is also worth recalling the broadest definition in terms of the analyzed regulation (Vide Article 4 point 1) [116]: 'veterinary medicinal product' means any substance or combination of substances which fulfils at least one of the following conditions:

(a) it is presented as having properties for treating or preventing disease in animals;

(b) its purpose is to be used in or administered to animals with a view to restoring, correcting, or modifying physiological functions by exerting a pharmacological, immunological, or metabolic action;

(c) its purpose is to be used in animals with a view to making a medical diagnosis;

(d) its purpose is to be used for euthanasia of animals.

Of key importance for the issue discussed is Art. 107 of the Regulation, which expressis verbis regulates the issues of the use of antimicrobial medicinal products. It shows, inter alia, that antimicrobial medicinal products cannot be used:

(a) antimicrobial medicinal products shall not be applied routinely nor used to compensate for poor hygiene, inadequate animal husbandry, or lack of care or to compensate for poor farm management;

(b) in animals for the purpose of promoting growth nor to increase yield;

(c) prophylaxis other than in exceptional cases for the administration to an individual animal or a restricted number of animals when the risk of an infection or of an infectious disease is very high, and the consequences are likely to be severe. In such cases, the use of antibiotic medicinal products for prophylaxis shall be limited to the administration to an individual animal only, under the conditions laid down in the first subparagraph.

A Member State may further restrict or prohibit the use of certain antimicrobials in animals on its territory if the administration of such antimicrobials to animals is contrary to the implementation of a national policy on prudent use of antimicrobials.

Antimicrobial medicinal products shall be used for metaphylaxis only when the risk of spread of an infection or of an infectious disease in the group of animals is high and where no other appropriate alternatives are available. Member States may provide guidance regarding such other appropriate alternatives and shall actively support the development and application of guidelines which promote the understanding of risk factors associated with metaphylaxis and include criteria for its initiation (Vide Article 107 Section 4) [116]. Antimicrobial medicinal products should not be used for prophylaxis other than in welldefined cases for the administration to an individual animal or restricted number of animals when the risk for infection is very high or its consequences are likely to be severe (Vide Article 107 Section 3) [116]. Member States should be able to allow the exceptional use of veterinary medicinal products without a marketing authorization where it is necessary to respond to Union-listed diseases or emerging diseases and where the health situation 
in a Member State so requires (Vide Section 26) [116]. It is worth emphasizing that the consequences of animal diseases, and at the same time the measures needed to combat them, can cause enormous damage to the entire population of animals, their owners, and thus the economy, and ultimately public health.

In order to fulfil the above-mentioned obligations as well as a whole range of other legal regulations regulated in the analyzed regulation Art. 107 Section 3, said Member States shall ensure that adequate financial resources are available to provide the staff and other resources necessary for the competent authorities to carry out the activities required by this Regulation [116].

The considerations carried out are only indicative, they undoubtedly prove that the widely understood processes of enactment, but above all the application of law, have a huge impact on the protection and guarantee of the highest level of public health and animal health protection as well as environmental protection. Otherwise, misuse (overuse of antibiotics) will lead to the spread of resistant pathogens, generally in animals, plants, and the environment and ultimately also in humans, representing one of the most serious global threats to public health.

The new legal regulation in the European Union does not limit the treatment of sick animals by administering them antibiotics, but its ratio legis excludes prophylactic treatment of the entire herd, with only a few diagnosed sick animals in the group. In other words, the EU legislator prohibits the massive and preventive use of antibiotics, e.g., in animal feed, water, etc. only for economic purposes. It should also be remembered that only effective supervision and control activities as well as monitoring studies of individual public administration bodies in all EU Member States will allow for a reliable assessment of the legitimacy and correctness of the use of antibiotics, and thus guarantee the protection of consumers against the consequences of their improper use.

The observation of the practice proves that in addition to the appropriate legal tools and organizational solutions, including the development of the principles of rational and safe use of antibiotics, the appropriate staffing of government and local government administration bodies to perform the above-mentioned duties is of key importance. Otherwise, staff shortages, insufficient level of financing, and high workloads will make the abovementioned tasks ineffective or perhaps more accurately simulated, due to staff fluctuations.

\section{Conclusions}

The greatest discovery of the 20th century was the control of many diseases, both animal and human with antibiotics. Unfortunately, the overuse of antibiotics has resulted in the appearance of drug-resistant pathogenic bacteria in veterinary practice and medicine. The main goal of large-scale livestock breeders is to intensify production and reduce mortality in the herd. An easy way to do this is to use antibiotics. Increased animal production keeps animals crowded, which facilitates the transmission of various diseases. As shown in the review, the use of probiotics on farms can naturally bring about a balance of gut microbes and reduce the growth of pathogens in broiler, pig, piglet, and cattle slaughter farms. Based on the review of the latest articles from 2021, an increase in interest in the effects caused by B. subtilis can be noticed (Table 1). The results indicate that it could be a substitute for antibiotics and an effective growth promoter in broiler breeding [55-58]. The use of probiotics is of increasing importance for the alleviation of weight and immunity deficiencies as well as for lowering the mortality ratio in broiler farms [117]. The discussed studies show the positive effect of LAB and its metabolites on the welfare of farm animals. The limitations of antibiotics in farms have a positive effect on the environment and living organisms, including humans. The application of the new regulations in the law, which will come into force in 2022, is to limit completely the use of antibiotics for disease prevention before they appear in the herd. This is the next step to reduce the occurrence of resistance effects among pathogenic bacteria.

Author Contributions: D.Z., conceptualization, writing—original draft preparation, review, editing, and Tables 1-3 preparation; A.N., conceptualization, supervision, Figure 1 preparation, review, 
and editing; I.N., writing-original draft preparation (paragraph 5: Antibiotics-Future Legal Regulations); and E.M.-P., conceptualization, supervision, and editing. All authors have read and agreed to the published version of the manuscript.

Funding: This research was funded by European Regional Development Fund, Poland, grant number RPLD.01.02.02-10-0005/16-00 and RPLD.01.02.02-10-0029/18-00.

Institutional Review Board Statement: Not applicable.

Data Availability Statement: Not applicable.

Acknowledgments: This work paper was completed while the first author was the Doctoral Candidate in the Interdisciplinary Doctoral School at the Lodz University of Technology, Poland.

Conflicts of Interest: The authors declare no conflict of interests.

\section{References}

1. Ma, X.; Yang, Z.; Xu, T.; Qian, M.; Jiang, X.; Zhan, X.; Han, X. Chlortetracycline alters microbiota of gut or faeces in pigs and leads to accumulation and migration of antibiotic resistance genes. Sci. Total Environ. 2021, 796, 148976. [CrossRef]

2. Schenkenfelder, J.; Winckler, C. Animal welfare outcomes and associated risk indicators on Austrian dairy farms: A cross-sectional study. J. Dairy Sci. 2021, 104, 11091-11107. [CrossRef]

3. Groot, M.J.; Berendsen, B.J.A.; Cleton, N.B. The Next Step to Further Decrease Veterinary Antibiotic Applications: Phytogenic Alternatives and Effective Monitoring; the Dutch Approach. Front. Vet. Sci. 2021, 8, 709750. [CrossRef]

4. Zhang, M.; Liu, Y.S.; Zhao, J.L.; Liu, W.R.; Chen, J.; Zhang, Q.Q.; He, L.Y.; Ying, G.G. Variations of antibiotic resistome in swine wastewater during full-scale anaerobic digestion treatment. Environ. Int. 2021, 155, 106694. [CrossRef] [PubMed]

5. Alliance to Save Our Antibiotics, Antibiotic Overuse in Livestock Farming. Available online: https:/ / www.saveourantibiotics. org/the-issue/antibiotic-overuse-in-livestock-farming/ (accessed on 8 November 2021).

6. World Health Organisation, Stop Using Antibiotics in Healthy Animals to Prevent the Spread of Antibiotic Resistance. Available online: https:/ / www.who.int/news/item/07-11-2017-stop-using-antibiotics-in-healthy-animals-to-prevent-the-spread-ofantibiotic-resistance (accessed on 8 November 2021).

7. Chiana's Multi-Story Hog Hotels Elevate Industrial Farms to Newleves. Available online: https://www.reuters.com/article/uschina-pigs-hotels-insight-idUSKBN1IB362 (accessed on 11 May 2021).

8. Graham, J.P.; Leibler, J.H.; Price, L.B.; Otte, J.M.; Pfeiffer, D.U.; Tiensin, T.; Silbergeld, E.K. The animal-human interface and infectious disease in indus-trial food animal production: Rethinking biosecurity and biocontainment. Public Health Rep. 2008, 123, 280-299. [CrossRef] [PubMed]

9. Leibler, J.H.; Dalton, K.; Pekosz, A.; Gray, G.C.; Silbergeld, E.K. Epizootics in in-dustrial livestock production: Preventable gaps in biosecurity and biocon-tainment. Zoonoses Public Health 2017, 64, 137-145. [CrossRef] [PubMed]

10. Agriculture, Forestry and Fishery Statistics-2020 Edition. Available online: https://ec.europa.eu/eurostat/documents/3217494/ 12069644/KS-FK-20-001-EN-N.pdf/a7439b01-671b-80ce-85e4-4d803c44340a?t=1608139005821 (accessed on 11 May 2021).

11. European Surveillance of Veterinary Antimicrobial Consumption. Sales of Veterinary Antimicrobial Agents in 31 European Countries in 2018. Available online: https:/ / www.ema.europa.eu/en/documents/report/sales-veterinary-antimicrobial-agents31-european-countries-2018-trends-2010-2018-tenth-esvac-report_en.pdf (accessed on 11 May 2021).

12. Banerjee, S.; Sar, A.; Misra, A.; Pal, S.; Chakraborty, A.; Dam, B. Increased productivity in poultry birds by sub-lethal dose of antibiotics is arbitrated by selective enrichment of gut microbiota, particularly short-chain fatty acid producers. Microbiology 2018, 164, 142-153. [CrossRef]

13. Graham, J.P.; Evans, S.L.; Price, L.B.; Silbergeld, E.K. Fate of antimicrobial-resistant enterococci and staphylococci and resistance determinants in stored poultry litter. Environ. Res. 2009, 109, 682-689. [CrossRef] [PubMed]

14. Salminen, S.; Collado, M.C.; Endo, A.; Hill, C.; Lebeer, S.; Quigley, E.; Sanders, M.E.; Shamir, R.; Swann, J.R.; Szajewska, H.; et al. The International Scientific Association of Probiotics and Prebiotics (ISAPP) consensus statement on the definition and scope of postbiotics. Nat. Rev. Gastroenterol. Hepatol. 2021, 18, 649-667. [CrossRef]

15. Williams, N.T. Probiotics. Am. J. Health Syst. Pharm. 2010, 67, 449-458. [CrossRef]

16. Zoumpopoulou, G.; Tzouvanou, A.; Mavrogonatou, E.; Alexandraki, V.; Georgalaki, M.; Anastasiou, R.; Papadelli, M.; Manolopoulou, E.; Kazou, M.; Kletsas, D.; et al. Probiotic Features of Lactic Acid Bacteria Isolated from a Diverse Pool of Traditional Greek Dairy Products Regarding Specific Strain-Host Interactions. Probiotics Antimicrob. Proteins 2018, 10, 313-322. [CrossRef] [PubMed]

17. Macuamule, C.L.; Wiid, I.J.; van Helden, P.D.; Tanner, M.; Witthuhn, R.C. Effect of milk fermentation by kefir grains and selected single strains of lactic acid bacteria on the survival of Mycobacterium bovis BCG. Int. J. Food Microbiol. 2016, 217, 170-176. [CrossRef] [PubMed]

18. Talib, N.; Mohamad, N.E.; Yeap, S.K.; Hussin, Y.; Aziz, M.; Masarudin, M.J.; Sharifuddin, S.A.; Hui, Y.W.; Ho, C.L.; Alitheen, N.B. Isolation and Characterization of Lactobacillus spp. from Kefir Samples in Malaysia. Molecules 2019, 24, 2606. [CrossRef] 
19. Touret, T.; Oliveira, M.; Semedo-Lemsaddek, T. Putative probiotic lactic acid bacteria isolated from sauerkraut fermentations. PLoS ONE 2018, 13, e0203501. [CrossRef]

20. Yu, Z.; Zhang, X.; Li, S.; Li, C.; Li, D.; Yang, Z. Evaluation of probiotic properties of Lactobacillus plantarum strains isolated from Chinese sauerkraut. World J. Microbiol. Biotechnol. 2013, 29, 489-498. [CrossRef] [PubMed]

21. Jeong, J.H.; Lee, C.Y.; Chung, D.K. Probiotic Lactic Acid Bacteria and Skin Health. Crit. Rev. Food Sci. Nutr. 2016, 56, 2331-2337. [CrossRef] [PubMed]

22. Naghmouchi, K.; Belguesmia, Y.; Bendali, F.; Spano, G.; Seal, B.S.; Drider, D. Lactobacillus fermentum: A bacterial species with potential for food preservation and biomedical applications. Crit. Rev. Food Sci. Nutr. 2020, 60, 3387-3399. [CrossRef]

23. Cui, X.; Shi, Y.; Gu, S.; Yan, X.; Chen, H.; Ge, J. Antibacterial and Antibiofilm Activity of Lactic Acid Bacteria Isolated from Traditional Artisanal Milk Cheese from Northeast China Against Enteropathogenic Bacteria. Probiotics Antimicrob. Proteins 2018, 10, 601-610. [CrossRef]

24. Pandey, K.R.; Naik, S.R.; Vakil, B.V. Probiotics, prebiotics and synbiotics-A review. J. Food Sci. Technol. 2015, $52,7577-7587$. [CrossRef]

25. Swanson, K.S.; Gibson, G.R.; Hutkins, R.; Reimer, R.A.; Reid, G.; Verbeke, K.; Scott, K.P.; Holscher, H.D.; Azad, M.B.; Delzenne, N.M.; et al. The International Scientific Association for Probiotics and Prebiotics (ISAPP) consensus statement on the definition and scope of synbiotics. Nat. Rev. Gastroenterol. Hepatol. 2020, 17, 687-701. [CrossRef]

26. Harper's Illustrated Biochemistry. Available online: http:/ /www.eqas.ir/pdf/lib/Harper\%20Illustrated\%20Biochemistry\%2020 03.pdf (accessed on 18 November 2021).

27. Śliżewska, K.; Markowiak-Kopeć, P.; Żbikowski, A.; Szeleszczuk, P. The effect of synbiotic preparations on the intestinal microbiota and her metabolism in broiler chickens. Sci. Rep. 2020, 10, 4281. [CrossRef] [PubMed]

28. Wang, L.; Li, L.; Lv, Y.; Chen, Q.; Feng, J.; Zhao, X. Lactobacillus plantarum restores intestinal permeability disrupted by Salmonella infection in newly-hatched chicks. Sci. Rep. 2018, 8, 2229. [CrossRef] [PubMed]

29. Olnood, C.G.; Beski, S.S.M.; Choct, M.; Iji, P.A. Use of Lactobacillus johnsonii in broilers challenged with Salmonella sofia. Anim. Nutr. 2015, 1, 203-212. [CrossRef] [PubMed]

30. Carter, A.; Adams, M.; La Ragione, R.M.; Woodward, M.J. Colonisation of poultry by Salmonella Enteritidis S1400 is reduced by combined administration of Lactobacillus salivarius 59 and Enterococcus faecium PXN-33. Vet. Microbiol. 2017, 199, 100-107. [CrossRef] [PubMed]

31. Wang, J.; Wan, C.; Shuju, Z.; Yang, Z.; Celi, P.; Ding, X.; Bai, S.; Zeng, Q.; Mao, X.; Xu, S.; et al. Differential analysis of gut microbiota and the effect of dietary Enterococcus faecium supplementation in broiler breeders with high or low laying performance. Poult. Sci. 2021, 100, 1109-1119. [CrossRef]

32. Penha Filho, R.A.; Díaz, S.J.; Fernando, F.S.; Chang, Y.F.; Andreatti Filho, R.L.; Berchieri Junior, A. Immunomodulatory activity and control of Salmonella Enteritidis colonization in the intestinal tract of chickens by Lactobacillus based probiotic. Vet. Immunol. Immunopathol. 2015, 167, 64-69. [CrossRef]

33. Prado-Rebolledo, O.F.; Delgado-Machuca, J.J.; Macedo-Barragan, R.J.; Garcia- Marquez, L.J.; Morales-Barrera, J.E.; Latorre, J.D.; Hermandez-Velasco, X.; Tellez, G. Evaluation of a selected lactic acid bacteria-based probiotic on Salmonella enterica serovar Entertitidis colonization and intestinal permeability in broiler chickens. Avian Pathol. 2017, 46, 90-94. [CrossRef]

34. Nishiyama, T.; Ashida, N.; Nakagawa, K.; Iwatani, S.; Yamamoto, N. Dietary Bacillus subtilis C-3102 Supplementation Enhances the Exclusion of Salmonella enterica from Chickens. J. Poult. Sci. 2021, 58, 138-145. [CrossRef]

35. Han, G.G.; Song, A.A.; Kim, E.B.; Yoon, S.H.; Bok, J.D.; Cho, C.S.; Kil, D.Y.; Kang, S.K.; Choi, Y.J. Improved antimicrobial activity of Pediococcus acidilactici against Salmonella Gallinarum by UV mutagenesis and genome shuffling. Appl. Microbiol. Biotechnol. 2017, 101, 5353-5363. [CrossRef]

36. Ščerbová, J.; Lauková, A. Sensitivity to Enterocins of Thermophilic Campylobacter spp. from Different Poultry Species. Foodborne Pathog. Dis. 2016, 13, 668-673. [CrossRef]

37. Razmyar, J.; Peighambari, S.M.; Zamani, A.H. Detection of a Newly Described Bacteriocin, Perfrin, Among Clostridium perfringens Isolates from Healthy and Diseased Ostriches and Broiler Chickens in Iran. Avian Dis. 2017, 61, 387-390. [CrossRef] [PubMed]

38. Neal-McKinney, J.M.; Lu, X.; Duong, T.; Larson, C.L.; Call, D.R.; Shah, D.H.; Konkel, M.E. Production of organic acids by probiotic lactobacilli can be used to reduce pathogen load in poultry. PLoS ONE 2012, 7, e43928. [CrossRef] [PubMed]

39. Weerts, E.; Matthijs, M.; Bonhof, J.; van Haarlem, D.A.; Dwars, R.M.; Gröne, A.; Verheije, M.H.; Jansen, C.A. The contribution of the immune response to enhanced colibacillosis upon preceding viral respiratory infection in broiler chicken in a dual infection model. Vet. Immunol. Immunopathol. 2021, 238, 110276. [CrossRef]

40. Li, T.; Castañeda, C.D.; Miotto, J.; McDaniel, C.; Kiess, A.S.; Zhang, L. Effects of in ovo probiotic administration on the incidence of avian pathogenic Escherichia coli in broilers and an evaluation on its virulence and antimicrobial resistance properties. Poult. Sci. 2021, 100, 100903. [CrossRef] [PubMed]

41. Tarabees, R.; Gafar, K.M.; El-Sayed, M.S.; Shehata, A.A.; Ahmed, M. Effects of Dietary Supplementation of Probiotic Mix and Prebiotic on Growth Performance, Cecal Microbiota Composition, and Protection against Escherichia coli O78 in Broiler Chickens. Probiotics Antimicrob. Proteins 2019, 11, 981-989. [CrossRef]

42. Kierończyk, B.; Sassek, M.; Pruszyńska-Oszmałek, E.; Kołodziejski, P.; Rawski, M.; Świątkiewicz, S.; Józefiak, D. The physiological response of broiler chickens to the dietary supplementation of the bacteriocin nisin and ionophore coccidiostats. Poult. Sci. 2017, 96, 4026-4037. [CrossRef] 
43. Metzler-Zebeli, B.U.; Molnár, A.; Hollmann, M.; Magowan, E.; Hawken, R.J.; Lawlor, P.G.; Zebeli, Q. Comparison of growth performance and excreta composition in broiler chickens when ranked according to various feed efficiency metrics. J. Anim. Sci. 2016, 94, 2890-2899. [CrossRef]

44. Hsu, S.T.; Breukink, E.; Tischenko, E.; Lutters, M.A.; de Kruijff, B.; Kaptein, R.; Bonvin, A.M.; van Nuland, N.A. The nisin-lipid II complex reveals a pyrophosphate cage that provides a blueprint for novel antibiotics. Nat. Struct. Mol. Biol. 2004, 11, 963-967. [CrossRef]

45. Fernández, L.; Delgado, S.; Herrero, H.; Maldonado, A.; Rodríguez, J.M. The bacteriocin nisin, an effective agent for the treatment of staphylococcal mastitis during lactation. J. Human Lact. 2008, 24, 311-316. [CrossRef]

46. Kierończyk, B.; Rawski, M.; Mikołajczak, Z.; Świątkiewicz, S.; Józefiak, D. Nisin as a Novel Feed Additive: The Effects on Gut Microbial Modulation and Activity, Histological Parameters, and Growth Performance of Broiler Chickens. Animals 2020, 10, 101. [CrossRef]

47. Wang, C.; Liu, Q.; Ye, F.; Tang, H.; Xiong, Y.; Wu, Y.; Wang, L.; Feng, X.; Zhang, S.; Wan, Y.; et al. Dietary purslane (Portulaca oleracea L.) promotes the growth performance of broilers by modulation of gut microbiota. AMB Express 2021, 11, 31. [CrossRef]

48. Liang, W.; Li, H.; Zhou, H.; Wang, M.; Zhao, X.; Sun, X.; Li, C.; Zhang, X. Effects of Taraxacum and Astragalus extracts combined with probiotic Bacillus subtilis and Lactobacillus on Escherichia coli-infected broiler chickens. Poult. Sci. 2021, 100, 101007. [CrossRef]

49. Nassik, S.; Tallouzt, S.; Karbach, N.; Touzani, C.; Bidoudan, Y.; Aamarine, N.; Hess, C. First Report of Isolation of Gallibacterium anatis from Layer Chickens in Morocco with Decrease in Laying Performance. Avian Dis. 2019, 63, 727-730. [CrossRef] [PubMed]

50. Allahghadry, T.; Ng, D.; Dibaei, A.; Bojesen, A.M. Clonal spread of multi-resistant Gallibacterium anatis isolates among Iranian broilers and layers. Vet. Res. 2021, 52, 27. [CrossRef] [PubMed]

51. Zhang, H.; HuangFu, H.; Wang, X.; Zhao, S.; Liu, Y.; Lv, H.; Qin, G.; Tan, Z. Antibacterial Activity of Lactic Acid Producing Leuconostoc mesenteroides QZ1178 Against Pathogenic Gallibacterium anatis. Front. Vet. Sci. 2021, 8, 630294. [CrossRef] [PubMed]

52. Wang, B.; Zhou, Y.; Mao, Y.; Gong, L.; Li, X.; Xu, S.; Wang, F.; Guo, Q.; Zhang, H.; Li, W. Dietary Supplementation With Lactobacillus plantarum Ameliorates Compromise of Growth Performance by Modulating Short-Chain Fatty Acids and Intestinal Dysbiosis in Broilers Under Clostridium perfringens Challenge. Front. Nutr. 2021, 8, 706148. [CrossRef]

53. Gong, L.; Wang, B.; Zhou, Y.; Tang, L.; Zeng, Z.; Zhang, H.; Li, W. Protective Effects of Lactobacillus plantarum 16 and Paenibacillus polymyxa 10 Against Clostridium perfringens Infection in Broilers. Front. Immunol. 2021, 11, 628374. [CrossRef]

54. Wu, Z.; Yang, K.; Zhang, A.; Chang, W.; Zheng, A.; Chen, Z.; Cai, H.; Liu, G. Effects of Lactobacillus acidophilus on the growth performance, immune response, and intestinal barrier function of broiler chickens challenged with Escherichia coli O157. Poult. Sci. 2021, 100, 101323. [CrossRef]

55. Zhang, S.; Zhong, G.; Shao, D.; Wang, Q.; Hu, Y.; Wu, T.; Ji, C.; Shi, S. Dietary supplementation with Bacillus subtilis promotes growth performance of broilers by altering the dominant microbial community. Poult. Sci. 2021, 100, 100935. [CrossRef]

56. Mohammed, A.A.; Zaki, R.S.; Negm, E.A.; Mahmoud, M.A.; Cheng, H.W. Effects of dietary supplementation of a probiotic (Bacillus subtilis) on bone mass and meat quality of broiler chickens. Poult. Sci. 2021, 100, 100906. [CrossRef]

57. Rivera-Pérez, W.; Barquero-Calvo, E.; Chaves, A.J. Effect of the use of probiotic Bacillus subtilis (QST 713) as a growth promoter in broilers: An alternative to bacitracin methylene disalicylate. Poult. Sci. 2021, 100, 101372. [CrossRef] [PubMed]

58. Wang, Y.; Heng, C.; Zhou, X.; Cao, G.; Jiang, L.; Wang, J.; Li, K.; Wang, D.; Zhan, X. Supplemental Bacillus subtilis DSM 29784 and enzymes, alone or in combination, as alternatives for antibiotics to improve growth performance, digestive enzyme activity, anti-oxidative status, immune response and the intestinal barrier of broiler chickens. Br. J. Nutr. 2021, 125, 494-507. [CrossRef] [PubMed]

59. Keerqin, C.; Rhayat, L.; Zhang, Z.H.; Gharib-Naseri, K.; Kheravii, S.K.; Devillard, E.; Crowley, T.M.; Wu, S.B. Probiotic Bacillus subtilis 29,784 improved weight gain and enhanced gut health status of broilers under necrotic enteritis condition. Poult. Sci. 2021, 100, 100981. [CrossRef] [PubMed]

60. He, Y.; Liu, X.; Dong, Y.; Lei, J.; Ito, K.; Zhang, B. Enterococcus faecium PNC01 isolated from the intestinal mucosa of chicken as an alternative for antibiotics to reduce feed conversion rate in broiler chickens. Microb. Cell Fact. 2021, 20, 122. [CrossRef] [PubMed]

61. Inoue, R.; Tsukahara, T.; Nakanishi, N.; Ushida, K. Development of the intestinal microbiota in the piglet. J. Gen. Appl. Microbiol. 2005, 51, 257-265. [CrossRef]

62. Knecht, D.; Srodon, S.A.; Duziński, K. The impact of season, parity and breed on selected reproductive performance parameters of sows. Arch. Anim. Breed. 2015, 58, 49-56. [CrossRef]

63. Chen, L.; Xu, Y.; Chen, X.; Fang, C.; Zhao, L.; Chen, F. The Maturing Development of Gut Microbiota in Commercial Piglets during the Weaning Transition. Front. Microbiol. 2017, 8, 1688. [CrossRef] [PubMed]

64. Li, P.; Niu, Q.; Wei, Q.; Zhang, Y.; Ma, X.; Kim, S.W.; Huang, R. Microbial shifts in the porcine distal gut in response to diets supplemented with Enterococcus faecalis as alternatives to antibiotics. Sci. Rep. 2017, 7, 41395. [CrossRef]

65. Mesonero-Escuredo, S.; Strutzberg-Minder, K.; Casanovas, C.; Segalés, J. Viral and bacterial investigations on the aetiology of recurrent pig neonatal diarrhoea cases in Spain. Porc. Health Manag. 2018, 4, 5. [CrossRef]

66. Shin, D.; Chang, S.Y.; Bogere, P.; Won, K.; Choi, J.Y.; Choi, Y.J.; Lee, H.K.; Hur, J.; Park, B.Y.; Kim, Y.; et al. Beneficial roles of probiotics on the modulation of gut microbiota and immune response in pigs. PLoS ONE 2019, 14, e0220843. [CrossRef]

67. Lo Verso, L.; Lessard, M.; Talbot, G.; Fernandez, B.; Fliss, I. Isolation and Selection of Potential Probiotic Bacteria from the Pig Gastrointestinal Tract. Probiotics Antimicrob. Proteins 2018, 10, 299-312. [CrossRef] [PubMed] 
68. Suda, Y.; Sasaki, N.; Kagawa, K.; Elean, M.; Zhou, B.; Tomokiyo, M.; Islam, M.A.; Rajoka, M.; Kober, A.; Shimazu, T.; et al. Immunobiotic Feed Developed with Lactobacillus delbrueckii subsp. delbrueckii TUA4408L and the Soymilk By-Product Okara Improves Health and Growth Performance in Pigs. Microorganism 2021, 9, 921. [CrossRef] [PubMed]

69. Chen, F.; Chen, J.; Chen, Q.; Yang, L.; Yin, J.; Li, Y.; Huang, X. Lactobacillus delbrueckii Protected Intestinal Integrity, Alleviated Intestinal Oxidative Damage, and Activated Toll-Like Receptor-Bruton's Tyrosine Kinase-Nuclear Factor Erythroid 2-Related Factor 2 Pathway in Weaned Piglets Challenged with Lipopolysacch. Antioxidants (Basel Switzerland) 2021, 10, 468. [CrossRef] [PubMed]

70. Fu, J.; Wang, T.; Xiao, X.; Cheng, Y.; Wang, F.; Jin, M.; Wang, Y.; Zong, X. Clostridium Butyricum ZJU-F1 Benefits the Intestinal Barrier Function and Immune Response Associated with Its Modulation of Gut Microbiota in Weaned Piglets. Cells 2021, 10, 527. [CrossRef]

71. Sobrino, O.J.; Alba, C.; Arroyo, R.; Pérez, I.; Sariego, L.; Delgado, S.; Fernández, L.; de María, J.; Fumanal, P.; Fumanal, A.; et al. Replacement of Metaphylactic Antimicrobial Therapy by Oral Administration of Ligilactobacillus salivarius MP100 in a Pig Farm. Front. Vet. Sci. 2021, 8, 666887. [CrossRef]

72. Hu, J.; Ma, L.; Nie, Y.; Chen, J.; Zheng, W.; Wang, X.; Xie, C.; Zheng, Z.; Wang, Z.; Yang, T.; et al. A Microbiota-Derived Bacteriocin Targets the Host to Confer Diarrhea Resistance in Early-Weaned Piglets. Cell Host Microbe 2018, 24, 817-832.e8. [CrossRef]

73. Moturi, J.; Kim, K.Y.; Hosseindoust, A.; Lee, J.H.; Xuan, B.; Park, J.; Kim, E.B.; Kim, J.S.; Chae, B.J. Effects of Lactobacillus salivarius isolated from feces of fast-growing pigs on intestinal microbiota and morphology of suckling piglets. Sci. Rep. 2021, 11, 6757. [CrossRef]

74. Le, N.; Bach, L.G.; Nguyen, D.C.; Le, T.; Pham, K.H.; Nguyen, D.H.; Hoang Thi, T.T. Evaluation of Factors Affecting Antimicrobial Activity of Bacteriocin from Lactobacillus plantarum Microencapsulated in Alginate-Gelatin Capsules and Its Application on Pork Meat as a Bio-Preservative. Int. J. Environ. Res. Public Health 2019, 16, 1017. [CrossRef]

75. Pupa, P.; Apiwatsiri, P.; Sirichokchatchawan, W.; Pirarat, N.; Maison, T.; Koontanatechanon, A.; Prapasarakul, N. Use of Lactobacillus plantarum (strains $22 \mathrm{~F}$ and $25 \mathrm{~F}$ ) and Pediococcus acidilactici (strain $72 \mathrm{~N}$ ) as replacements for antibiotic-growth promotants in pigs. Sci. Rep. 2021, 11, 12028. [CrossRef]

76. Wang, J.; Ji, H.F.; Hou, C.L.; Wang, S.X.; Zhang, D.Y.; Liu, H.; Shan, D.C.; Wang, Y.M. Effects of Lactobacillus johnsonii XS4 supplementation on reproductive performance, gut environment, and blood biochemical and immunological index in lactating sows. Livest. Sci. 2014, 164, 96-101. [CrossRef]

77. Wang, W.; Ma, H.; Zhu, Y.; Ni, K.; Qin, G.; Tan, Z.; Wang, Y.; Wang, L.; Pang, H. Screening of Lactic Acid Bacteria with Inhibitory Activity against ETEC K88 as Feed Additive and the Effects on Sows and Piglets. Animals 2021, 11, 1719. [CrossRef] [PubMed]

78. Lan, R.; Kim, I. Enterococcus faecium supplementation in sows during gestation and lactation improves the performance of sucking piglets. Vet. Med. Sci. 2020, 6, 92-99. [CrossRef]

79. Mori, K.; Ito, T.; Miyamoto, H.; Ozawa, M.; Wada, S.; Kumagai, Y.; Matsumoto, J.; Naito, R.; Nakamura, S.; Kodama, H.; et al. Oral administration of multispecies microbial supplements to sows influences the composition of gut microbiota and fecal organic acids in their post-weaned piglets. J. Biosci. Bioeng. 2011, 112, 145-150. [CrossRef]

80. Betancur, C.; Martínez, Y.; Tellez-Isaias, G.; Castillo, R.; Ding, X. Effect of Oral Administration with Lactobacillus plantarum CAM6 Strain on Sows during Gestation-Lactation and the Derived Impact on Their Progeny Performance. Mediat. Inflamm. 2021, 2021, 6615960. [CrossRef] [PubMed]

81. Geng, T.; Su, S.; Sun, K.; Zhao, L.; Zhao, Y.; Bao, N.; Pan, L.; Sun, H. Effects of feeding a Lactobacillus plantarum JL01 diet on caecal bacteria and metabolites of weaned piglets. Lett. Appl. Microbiol. 2021, 72, 24-35. [CrossRef]

82. Geng, T.; He, F.; Su, S.; Sun, K.; Zhao, L.; Zhao, Y.; Bao, N.; Pan, L.; Sun, H. Probiotics Lactobacillus rhamnosus GG ATCC53103 and Lactobacillus plantarum JL01 induce cytokine alterations by the production of TCDA, DHA, and succinic and palmitic acids, and enhance immunity of weaned piglets. Res. Vet. Sci. 2021, 137, 56-67. [CrossRef] [PubMed]

83. Cheng, S.; Chen, M.; Gao, M.; Qiu, T.; Tian, S.; Li, S.; Wang, X. Effects of Enterococcus faecalis administration on the community structure of airborne bacteria in weanling piglet and layer hen houses. J. Gen. Appl. Microbiol. 2021, 67, 162-169. [CrossRef]

84. Wang, C.; Wei, S.; Xu, B.; Hao, L.; Su, W.; Jin, M.; Wang, Y. Bacillus subtilis and Enterococcus faecium co-fermented feed regulates lactating sow's performance, immune status and gut microbiota. Microb. Biotechnol. 2021, 14, 614-627. [CrossRef]

85. Pu, J.; Chen, D.; Tian, G.; He, J.; Zheng, P.; Mao, X.; Yu, J.; Huang, Z.; Luo, J.; Luo, Y.; et al. Effects of benzoic acid, Bacillus coagulans and oregano oil combined supplementation on growth performance, immune status and intestinal barrier integrity of weaned piglets. Anim. Nutr. 2020, 6, 152-159. [CrossRef]

86. Fu, R.; Liang, C.; Chen, D.; Yan, H.; Tian, G.; Zheng, P.; He, J.; Yu, J.; Mao, X.; Huang, Z.; et al. Effects of dietary Bacillus coagulans and yeast hydrolysate supplementation on growth performance, immune response and intestinal barrier function in weaned piglets. J. Anim. Physiol. Anim. Nutr. 2021, 105, 898-907. [CrossRef]

87. Hrala, M.; Bosák, J.; Micenková, L.; Křenová, J.; Lexa, M.; Pirková, V.; Tomáštíková, Z.; Koláčková, I.; Šmajs, D. Escherichia coli Strains Producing Selected Bacteriocins Inhibit Porcine Enterotoxigenic Escherichia coli (ETEC) under both In Vitro and In Vivo Conditions. Appl. Environ. Microbiol. 2021, 87, e0312120. [CrossRef] [PubMed]

88. Tian, Z.; Cui, Y.; Lu, H.; Wang, G.; Ma, X. Effect of long-term dietary probiotic Lactobacillus reuteri 1 or antibiotics on meat quality, muscular amino acids and fatty acids in pigs. Meat Sci. 2021, 171, 108234. [CrossRef] [PubMed]

89. Zhang, P.; Huang, L.; Zhang, E.; Yuan, C.; Yang, Q. Oral administration of Bacillus subtilis promotes homing of CD3 ${ }^{+} \mathrm{T}$ cells and IgA-secreting cells to the respiratory tract in piglets. Res. Vet. Sci. 2021, 136, 310-317. [CrossRef] [PubMed] 
90. De Vliegher, S.; Fox, L.K.K.; Piepers, S.; McDougall, S.; Barkema, H.W. Invited review: Mastitis in dairy heifers: Nature of the disease, potential impact, prevention, and control. J. Dairy Sci. 2012, 95, 1025-1040. [CrossRef]

91. Bian, Y.; Lv, Y.; Li, Q. Identification of diagnostic protein markers of subclinical mastitis in bovine whey using comparative proteomics. Bull. Vet. Inst. Pulawy 2014, 58, 385-392. [CrossRef]

92. Shaheen, M.; Tantary, H.; Nabi, S. A treatise on bovine mastitis: Disease and disease economics, etiological basis, risk factors, impact on human health, therapeutic management, prevention and control strategy. J. Adv. Dairy Res. 2016, 4, 1-10. [CrossRef]

93. Dalanezi, F.M.; Joaquim, S.F.; Guimarães, F.F.; Guerra, S.T.; Lopes, B.C.; Schmidt, E.; Cerri, R.; Langoni, H. Influence of pathogens causing clinical mastitis on reproductive variables of dairy cows. J. Dairy Sci. 2020, 103, 3648-3655. [CrossRef]

94. Gryaznova, M.V.; Syromyatnikov, M.Y.; Dvoretskaya, Y.D.; Solodskikh, S.A.; Klimov, N.T.; Mikhalev, V.I.; Zimnikov, V.I.; Mikhaylov, E.V.; Popov, V.N. Microbiota of Cow's Milk with Udder Pathologies. Microorganisms 2021, 9, 1974. [CrossRef]

95. Crispie, F.; Alonso-Gómez, M.; O’Loughlin, C.; Klostermann, K.; Flynn, J.; Arkins, S.; Meaney, W.; Paul Ross, R.; Hill, C. Intramammary infusion of a live culture for treatment of bovine mastitis: Effect of live lactococci on the mammary immune response. J. Dairy Res. 2008, 75, 374-384. [CrossRef]

96. Abebe, R.; Hatiya, H.; Abera, M.; Megersa, B.; Asmare, K. Bovine mastitis: Prevalence, risk factors and isolation of Staphylococcus aureus in dairy herds at hawassa milk shed, South Ethiopia. BMC Vet. Res. 2016, 12, 270. [CrossRef]

97. Bi, Y.; Wang, Y.J.; Qin, Y.; Vallverdú, R.G.; García, J.M.; Sun, W.; Li, S.; Cao, Z. Prevalence of Bovine Mastitis Pathogens in Bulk Tank Milk in China. PLoS ONE 2016, 11, e0155621. [CrossRef] [PubMed]

98. Taponen, S.; Liski, E.; Heikkilä, A.-M.; Pyörälä, S. Factors associated with intramammary infection in dairy cows caused by coagulase-negative staphylococci, Staphylococcus aureus, Streptococcus uberis, Streptococcus dysgalactiae, Corynebacterium bovis, or Escherichia coli. J. Dairy Sci. 2017, 100, 493-503. [CrossRef] [PubMed]

99. McDougall, S.; Clausen, L.; Hintukainen, J.; Hunnam, J. Randomized, controlled, superiority study of extended duration of therapy with an intramammary antibiotic for treatment of clinical mastitis. J. Dairy Sci. 2019, 102, 4376-4386. [CrossRef]

100. Wichmann, F.; Udikovic-kolic, N.; Andrew, S. Diverse antibiotic resistance genes in dairy cow manure. MBio 2014,5 , e01017. [CrossRef]

101. Field, D.; Considine, K.; O'Connor, P.M.; Ross, R.P.; Hill, C.; Cotter, P.D. Bio-Engineered Nisin with Increased Anti-Staphylococcus and Selectively Reduced Anti-Lactococcus Activity for Treatment of Bovine Mastitis. Int. J. Mol. Sci. 2021, 22, 3480. [CrossRef]

102. Godoy-Santos, F.; Pinto, M.S.; Barbosa, A.A.T.; Brito, M.A.V.P.; Mantovani, H.C. Efficacy of a Ruminal Bacteriocin Against Pure and Mixed Cultures of Bovine Mastitis Pathogens. Indian J. Microbiol. 2019, 59, 304-312. [CrossRef]

103. Pimentel-Filho, N.J.; Mantovani, H.C.; Diez- Gonzalez, F.; Vanetti, M.C.D. Inhibition of Listeria and Staphylococcus aureus by bovicin HC5 and nisin combination in milk. J. Agric. Sci. 2013, 5, 188-196. [CrossRef]

104. Prudencio, C.V.; Mantovani, H.C.; Cecon, P.R.; Vanetti, M.C. Differences in the antibacterial activity of nisin and bovicin HC5 against Salmonella Typhimurium under different temperatures and $\mathrm{pH}$ conditions. J. Appl. Microbiol. 2015, 118, 18-26. [CrossRef] [PubMed]

105. Kitching, M.; Mathur, H.; Flynn, J.; Byrne, N.; Dillon, P.; Sayers, R.; Rea, M.C.; Hill, C.; Ross, R.P. A Live Bio-Therapeutic for Mastitis, Containing Lactococcus lactis DPC3147 With Comparable Efficacy to Antibiotic Treatment. Front. Microbiol. 2019, 10, 2220. [CrossRef]

106. Malvisi, M.; Stuknytè, M.; Magro, G.; Minozzi, G.; Giardini, A.; De Noni, I.; Piccinini, R. Antibacterial activity and immunomodulatory effects on a bovine mammary epithelial cell line exerted by nisin A-producing Lactococcus lactis strains. J. Dairy Sci. 2016, 99, 2288-2296. [CrossRef]

107. Piccart, K.; Vásquez, A.; Piepers, S.; De Vliegher, S.; Olofsson, T.C. Short communication: Lactic acid bacteria from the honeybee inhibit the in vitro growth of mastitis pathogens. J. Dairy Sci. 2016, 99, 2940-2944. [CrossRef] [PubMed]

108. Kim, S.G.; Lee, Y.D.; Park, J.H.; Moon, G.S. Synergistic Inhibition by Bacteriocin and Bacteriophage against Staphylococcus aureus. Food Sci. Anim. Resour. 2019, 39, 1015-1020. [CrossRef] [PubMed]

109. Pholsen, S.; Khota, W.; Pang, H.; Higgs, D.; Cai, Y. Characterization and application of lactic acid bacteria for tropical silage preparation. Anim. Sci. J. 2016, 87, 1202-1211. [CrossRef] [PubMed]

110. Chotigarpa, R.; Lampang, K.N.; Pikulkaew, S.; Okonogi, S.; Silman, P.; Mektrirat, R. Antiseptic effect of natural teat dip containing lactic acid against mastitis-causing Escherichia coli. Vet. World 2019, 12, 397-401. [CrossRef]

111. Chotigarpa, R.; Na Lampang, K.; Pikulkaew, S.; Okonogi, S.; Ajariyakhajorn, K.; Mektrirat, R. Inhibitory Effects and Killing Kinetics of Lactic Acid Rice Gel Against Pathogenic Bacteria Causing Bovine Mastitis. Sci. Pharm. 2018, 86, E29. [CrossRef]

112. Lin, W.C.; Ptak, C.P.; Chang, C.Y.; Ian, M.K.; Chia, M.Y.; Chen, T.H.; Kuo, C.J. Autochthonous Lactic Acid Bacteria Isolated From Dairy Cow Feces Exhibiting Promising Probiotic Properties and in vitro Antibacterial Activity Against Foodborne Pathogens in Cattle. Front. Vet. Sci. 2020, 7, 239. [CrossRef]

113. Blanchet, F.; Rault, L.; Peton, V.; Le Loir, Y.; Blondeau, C.; Lenoir, L.; Dubourdeaux, M.; Even, S. Heat inactivation partially preserved barrier and immunomodulatory effects of Lactobacillus gasseri LA806 in an in vitro model of bovine mastitis. Benef. Microbes 2021, 12, 95-106. [CrossRef]

114. Antymicrobial Resistance in G7 Countries and Beyond: Economic Issues, Policies and Options for Action. Available online: https:/ / www.oecd.org/els/health-systems / Antimicrobial-Resistance-in-G7-Countries-and-Beyond.pdf (accessed on 16 October 2021). 
115. Raport NIK z Dnia 31 Października 2017 r. pt. Wykorzystywanie Antybiotyków w Produkcji Zwierzęcej w Województwie Lubuskim. Available online: https://www.nik.gov.pl/plik/id,16219,vp,18743.pdf (accessed on 16 October 2021).

116. Regulation (EU) $2019 / 6$ of The European Parliament and of the Council of 11 December 2018 on Veterinary Medicinal Products and Repealing Directive 2001/82/EC. Available online: https:/ / eur-lex.europa.eu/legal-content/EN/TXT/PDF/?uri=CELEX: 32019R0006\&from=EN (accessed on 26 August 2021).

117. Sandvang, D.; Skjoet-Rasmussen, L.; Cantor, M.D.; Mathis, G.F.; Lumpkins, B.S.; Blanch, A. Effects of feed supplementation with 3 different probiotic Bacillus strains and their combination on the performance of broiler chickens challenged with Clostridium perfringens. Poult. Sci. 2021, 100, 100982. [CrossRef] [PubMed] 